\title{
The U.S.-Proposed "Trusteeship Agreement" for Palestine: The UN-Styled Plan That Could Have Avoided Forcible Displacement of the Palestinian Refugees in 1948
}

\author{
Gail J. Boling
}

\section{Abstract}

In this article, the author examines the U S.-proposed "Trusteeship A greement for Palestine," circulated by the U.S. in the UN Security Council and in subcommittees of the General Assembly from M arch through M ay of 1948. The U.S. proposed a UN trusteeship for Palestine as a possible means to provide for a peaceful transition from the end of the British $\mathrm{M}$ andate for Palestine into a new governmental entity that would provide equality under the law for all of its citizens. N otably, the proposed trusteeship arrangement would have avoided partition of Palestine. The author asserts that this, in turn, could have avoided the forcible displacement of three-quarters of a million Palestinian refugees in 1948, as well as I srael's subsequent re fusal to repatriate them. The author argues that the U .S.-proposed Trusteeship Agreement for Palestine sheds light on important norms of international law that existed in 1948 and that could, and should, have been followed by the U nited Nations in providing for the welfareand le gal rights of all the inhabitants of mandate Palestineas the clock ticked down on the announced British withdrawal from Palestineas mandatory authority as of $15 \mathrm{M}$ ay 1948.

\section{Résumé}

Dans cet article, l'auteure examine la proposition intitulée «Trusteeship Agreement for Palestine» («Accord de tutelle pour la Palestine») qu'avait fait circuler les ÉtatsU nis au Conseil de sécurité des $\mathrm{N}$ ations $U$ nies et dans les sous-comités de l'Assemblée générale pendant la période allant de mars à mai 1948. LesÉtats-U nis avaient proposé une tutelle des $\mathrm{N}$ ations U nies pour la Palestine comme solution possible pouvant fournir une transition pacifique entre la fin du mandat britannique sur la Palestine et l'émergence d'une nouvelle entité gouvernementale qui aurait garanti l'égalité de tous ses citoyens devant la loi. En particulier, ce plan de tutelle aurait évité la partition de la Palestine. L'auteur affirmequ'un tel plan aurait à son tour évitéle déplacement forcé de trois-quarts de million de réfugiés palestiniens en 1948, aussi bien quele refus d'I sraël par la suite de les rapatrier. L'auteur soutient que la proposition américained' "Accord de Tutelle des N ations U nies pour la Palestine » jette la lumière sur des normes importantes en matière de droit international qui existaient en 1948 et qui auraient pu, et auraient dû, être mises en vigueur par les $\mathrm{N}$ ations U nies pour garantir le bien-être et les droits légaux de tous les habitants du mandat de la Palestine alors qu'avait commencé le compte à rebours pour le retrait annoncé de la Grande Bretagne de la Palestine en tant qu'autorité mandataire, le 15 mai 1948. 


\section{Introduction}

his article will examine an important but often overlooked document that had thepotential peacefully to forestall the outbreak of interstate hostilities in the Israeli-Palestinian conflict in 1948. This document is the U.S.-proposed "Trusteeship Agreement for Palestine" ${ }^{1}$ (hereinafter the Trusteeship Agreement), drafted by the U.S. and circulated first in the UN Security Council and then in subcommittees of the General Assembly from $\mathrm{M}$ arch through M ay of 1948. H ad this plan been adopted by theUN Security Council in a timely manner in 1948, it could quite possibly have avoided ${ }^{2}$ or reversed ${ }^{3}$ the forcible displacement of the Palestinian refugee population in 1948. Consequently, study of the Trusteeship Agreement sheds light on certain important international law aspects of the Palestinian refugee dilemma, both at itsoriginsand also at the heart of the current stalemate in the stalled peace negotiations between the Israelis and the Palestinians.

The Trusteeship Agreement would have legally obliged United Nations member states to ensure the peaceful transition of the "British Mandate for Palestine" - which the British had announced they would terminate on $15 \mathrm{M}$ ay 1948 - into a newly created entity to be known as the "UN Trusteeship for Palestine" (hereinafter the Trusteeship). This new Trusteeship would have been supervised under the UN Trusteeship Council pursuant to Article 75 of the Charter of the $U$ nited N ations. ${ }^{4}$

The potential impact of the Trusteeship Agreement in changing the course of history of the Israeli-Palestinian conflict cannot be underestimated. Had it comeinto effect, there would have been no division of mandate Palestine into more than one state. The government that would have been set up - under the direct supervision of the United Nations- would have been a government for all its citizens. Because it was premised on a peaceful transition of government, forcible displacement of habitual residents from the territory of former mandatePalestine and subsequent refusal to repatriate them simply was not contemplated in the setting up of such a Trusteeship, nor could it have been justified under the terms of the Trusteeship Agreement. This is because the Trusteeship Agreement incorporated certain fundamental human rights norms that have come to be recognized as forming the bedrock core of human rights law today. Seen in this light, the importance of the Trusteeship Agreement becomes clear. From the viewpoint of the Palestinians who became refugees, it could have protected them from forcible displacement and Israel's subsequent refusal to repatriate them. From the viewpoint of theY ishuv - the pre-state, Zionist politically oriented and immigrant-based leadership operating in Pal estine- implementation of the Trusteeship Agreement would have been an unmitigated disaster and could well have spelled the end of theZionist enterprise. The stakes surrounding the fate of the Trusteeship Agreement, then, were a "winner takes all" proposition.

In its most basic outlines, the Trusteeship Agreement would have instituted a secular and democratic model of government in all the geographic area of former mandate Palestine. Thus, "partition" - or separation of the two peoples, Jewish vs. Palestinian Arab - simply was not contemplated under Trusteeship. This commitment to geographic unity alone would have avoided the creation of the Palestinian refugee population. Under Trusteeship, there could have been no possiblejustification for forcibledisplacement and subsequent refusal to repatriate refugees whose habitual residences lay inside the geographic boundaries of the Trusteeship entity. Furthermore, the Trusteeship Agreement incorporated fundamental human rights principles that would have protected Palestinians, including: democratic rule through the ballot; 5 equal ity under the law for all citizens of the Trusteeship; protection of property rights for all citizens of the Trusteeship; and a secular government, following the U.S. model of "separation of church (religion) and state." A tripartite system of government was proposed, with legislative, judicial, and executive branches.

Review of the Trusteeship Agreement, then, is not mere hypothetical speculation about what "might have been" or an idle exercisein "rewriting history" for purely conjectural reasons. Rather, the analysis is important because it provides an actual historical example of a governmental model that was actually proposed at thehighest levels of the U nited Nations and could have been used for the peaceful transition of mandate Palestine into a new governmental entity - Trusteeship - which in turn was intended to lead to full self-government or independence. This model is critically important because it was drafted within the framework of the United Nations system and consciously incorporated fundamental norms of the United Nations human rights regime existing in 1948 to define the contours of the type of government envisioned for post-mandate Palestine. Thus the Trusteeship Agreement serves as a standard-setting model that incorporates 1948 legal norms that should have guided the fate of post-mandate Palestine.

Viewing the issue in terms of the present-day impasse facing negotiations between the Israelis and the Palestinians, analysts on both sides of the tableagree unanimously that if a solution to the Palestinian refugee problem could be found, then a solution to the I sraeli-Palestinian conflict could be found. Israel's refusal to offer the choice of voluntary repatriation to the 1948 refugees and their descendants remains the most intractable of the so-called "final status" 
issues still on the negotiating table between the I sraelis and the Palestinians today.

Does the past hold any keys to solving the perplexing dilemma of the Palestinian refugee question, which has such monumental consequences for achieving peace and stability in the M iddle East in these troubled times? Do the legal norms incorporated into the 1948 UN Trusteeship Agreement for Palestine offer any guidelines or benchmarks that could be used in mapping out a solution to the Palestinian refugee question today?

This article will attempt to suggest somepossibleanswers to these questions. First, a bri ef survey of the history leading up to the official U.S. proposal for the Trusteeship Agreement will be presented. Then, the more salient features of the Trusteeship government itself will be examined. Then the Trusteeship proposal will be examined in light of light of international law. I t will then bepossibleto arrive at some concluding observations.

\section{Historical Background}

The Covenant of the League of $\mathrm{N}$ ations: $\mathrm{M}$ andates as a "Sacred Trust of Civilization"

To understand the particularities of the British mandate for Palestine, established in 1922, it is first necessary to review the mandates scheme devised by the League of Nations following W orld War I and set out in the 1919 Covenant of the League of Nations (hereinafter the Covenant). ${ }^{6}$ The victorious allied powers envisioned a scheme of "administering" various colonies that had previously been under the control of Germany and Turkey until their defeat during the war. Three classes of mandates were envisioned: "Class $A$," "Class B," and "Class C" mandates. The "Class A" mandates wereintended for themost "developed" peoples, which were therefore deemed capable of achieving independence the soonest. "Class B" mandates were for "less developed" peoples, and "Class C" mandates were for the "least developed" peoples. The League of Nations envisaged that "Class A" mandates would achieve full independencefirst, followed by the "ClassB" mandates, and then by the "ClassC" mandates. H owever, no specific timetables or "road maps" for achieving independence were laid out in the Covenant. ${ }^{7}$

Article 22(4) of the Covenant contains the language that specifically addresses the sovereignty rights of peoples under "Class A" mandates. The language defining the legal contours of the mandate concept generally is contained in thefirst four paragraphs of Article22, which read asfollows:

\section{Article 22:}

To those colonies and territories which as a consequence of the latewar have ceased to beunder the sovereignty of theStates which formerly governed them and which are inhabited by peoples not yet able to stand by themselves under thestrenuous conditions of the modern world, there should be applied the principle that the well-being and development of such peoples form a sacred trust of civilization and that securities for the performance of this trust should be embodied in this Covenant.

The best method of giving practical effect to this principle is that the tutelage of such peoples should be entrusted to advanced nations who by reason of their resources, their experience or their geographical position can best undertake this responsibility, and who are willing to accept it, and that this tutelage should be exercised by them as $M$ andatories on behalf of the League.

The character of the mandate must differ according to the stage of the development of the people, the geographical situation of the territory, its economic conditions and other similar circumstances.

Certain communities formerly belonging to the Turkish Empire have reached a stage of development where their existence as independent nations can be provisionally recognized subject to the rendering of administrative advice and assistance by a M andatory until such timeas they are ableto stand alone. The wishes of these communities must be a principal consideration in the selection of the $M$ andatory. [emphasis added] ${ }^{8}$

There are three main points to be made here. First, the mandates system was en visaged, as early as 1919, as a "sacred trust of civilization." The legal concept of "trust" (or trusteeship) in Anglo-Saxon common law is specifically invoked in Article22 in paragraphs 1 and 2, through use of the words "sacred trust," "securities for the performance of this trust," "tutelage of such peoples should beentrusted," and "advanced nations [undertake the tutelage]... on behalf of the League."

According to the Anglo-Saxon common-law understanding of "trust" in property and estate law (equity), a "trustee" who is charged with custodial responsibilities for managing property that belongs to one party (the "grantor") for the benefit of another party (the "beneficiary") does not (and legally cannot) acquire actual ownership of that property (the "corpus" of thetrust). Rather, thetrustee has strict obligations to manage the property responsibly and can be held legally liable for mismanagement. The management responsibilities of the trustee are known as "fiduciary" duties and the duty of care is extremely high. Therearevery few circumstances in which mismanagement or waste by a trustee is excused by common law courts. ${ }^{9}$

The use of the "trust" language in Article 22 of the Covenant is significant for this reason. Britain was obligated to perform its trust obligations under any League of Nations mandate in a responsible fashion, so as not to violate its strict common law fiduciary duties as "trustee." 
The "property" in this case is the concept of "national sovereignty" of the local inhabitants of the mandated territory, whose sovereignty rights were to be temporarily " $\mathrm{ma}$ naged" by the mandatory "trustee" until full independence would be achieved. ${ }^{10}$ Article 22 makes it clear that the mandates are a "trust" arrangement in which the "beneficiaries" are the peoples of the mandated territories themselves. ${ }^{11}$ Britain's "fiduciary duties" and strict duty of care becomes significant when analyzing its decision to incorporate the Balfour Declaration into the British $M$ andatefor Palestine (see below).

The second point to be made here is that Article 22(4) specifically refers to the geographical area that formerly had been occupied by the Turkish Empire. This area, which included Palestine, wasultimately divided into fiveseparate mandate areas - Palestine, Trans-J ordan, Lebanon, Syria, and Iraq - all of which were denominated "Class A" mandates because they were deemed to be the most ready to achieve their full sovereign independence and were expected to do so sooner than the "Class B" or "Class C" mandates. Of the five "Class A" mandates, Palestine was the only one that did not achieve the full sovereign independence promised to it in Article 22(4). I raq achieved independence first, in 1932, when it was admitted to the League of $\mathrm{N}$ ations. Jordan achieved independencein 1946. TheFrench mandates over Syria and Lebanon ended during W orld War II.

At least one author has disputed the clarity of the geographical reference contained in Article 22(4), arguing that use of the words "certain communities" - without specifying exactly which ones - is vague and leaves open the possibility that not all "communities formerly belonging to the Turkish Empire" were "provisionally recognized" as "independent nations." That commentator argues that Palestine was the exception, and that the local indigenous inhabitants of Palestine did not receive provisional recognition in Article 22(4) of their status as an independent nation because of the vagueness of the wording. ${ }^{12} \mathrm{H}$ owever, this argument fails to address the fact that Palestine was expressly grouped in the "Class A" mandates by the League of $\mathrm{Nations}$ along with all the other territories formerly occupied by the Ottoman Turks. Since thereis no language in Article 22(4) to separate Palestine out for disparatetreatment, it should logically be considered to have been included in the Covenant's provisional recognition of sovereignty as an independent nation.

The Balfour Dedaration: Propriety of Incorporation into the British $\mathrm{M}$ andate for Palestine

The third point to be made concerns the Balfour Declaration, which preceded the drafting of the Covenant of the League of Nations. The Balfour Declaration was a letter written in 1917 by Britain's Foreign Secretary, Arthur Balfour, to a prominent leader of the Zionist movement, Lord Rothschild, stating that Britain would "view with favour the establishment in Palestine of a national home for the Jewish people." ${ }^{13}$ The Balfour Declaration was a letter written by a representative of the British government to a private person and therefore could not be considered binding upon any other states (and some Britons questioned whether it could even be considered binding upon Britain). Importantly, however, the Balfour Declaration did contain a "savings clause" which preserved the rights of the local, indigenous inhabitants of Palestine: "it being clearly understood that nothing shall be done which may prejudice the civil and religious rights of existing non-Jewish communities in $\mathrm{Pa}$ lestine."14

In contrast, the Covenant of the League of Nations, as discussed above, was an agreement made between states two years later, in 1919. The Covenant served as the juridical basis for the mandates which the League subsequently set up. Britain, which ultimately assumed the mandate for Palestine in 1922, did so subject to the express terms of the Covenant. Thus, Article 22 of the Covenant must serve as the benchmark for measuring Britain's performance of its fiduciary trust obligations to the "beneficiaries" of the Covenant trust, i.e., the local indigenous inhabitants of Palestine. Britain notably acted against this people's interests by incorporating theterms of the Balfour Declaration into the British M andatefor Palestinein $1922 .{ }^{15}$ It can beargued that Britain's actions in so doing were ultra vires to the express terms of Article 22 of the Covenant. Indeed, the Palestinian Arab population was quite vocal about its opposition to the incorporation of the Balfour Declaration into the British $M$ andatefor Palestineand persistently questioned the legality of this incorporation throughout the twenty-five years that Britain served as the mandatory authority. The historical record is replete with examples of the Palestinian Arab population raising legal challenges to this incorporation and the Yishuv preferring to avoid having these challenges heard by bodies capable of making a conclusive legal judgment. ${ }^{16}$

Britain essentially attempted to do the impossible. On the one hand, it attempted to satisfy the fiduciary requirements of the Covenant, which entailed safeguarding the sovereignty rights of the local indigenous population over whom it had assumed mandatory authority. That is why the terms of the British $M$ andate for Palestineincluded numerous "savings clauses," intended to protect this people's rights. ${ }^{17} \mathrm{H}$ owever, on the other hand, Britain gave the wink and nod to another group of people - notably immigrants from outside the region - and gave them permission to settle in Palestine to create a new society or "homeland" 
(which the immigrant population interpreted as permission to try to establish their own state). The indigenous population never accepted the notion that the immigrants could set up their own state at the expense of the rights of the indigenous population.

Twenty-Five Years Later, Britain Announces W ithdrawal from Palestine: What Will Fill the Gap?

For twenty-five years - from 1922 to 1947 - Britain played the game of trying to square the circle by attempting to satisfy thepolitical demands of two different groups competing over the same territory. Eventually, however, realizing the impossibility of such a proposition, Britain threw up its hands in despair and in April 1947 announced its intention of withdrawing as mandatory authority in Palestine (originally giving an exit date of 1 August 1948, but subsequently moving theexit dateup to $15 \mathrm{M}$ ay 1948). This threw thematter of devising a substitute government structure for Palestine squarely into the purview of the United $N$ ations.

General Assembly Recommends "Partition" of Palestine29 N ovember 1947

The U nited Nations General Assembly initially proposed in November 1947 that Palestine be "partitioned," in effect proposing to cut the proverbial Solomonic baby in half. On 29 N ovember 1947, the General Assembly adopted Resolution $181,{ }^{18}$ known as the "Partition Resolution," which recommended dividing mandatory Palestine into two states, which wereinaccurately denominated the "Jewish state" and "Arab state." 19 However, the General Assembly has only recommendatory powers under Articles 10, 11, and 14 of the Charter of the United Nations. ${ }^{20}$ Only Security Council resolutions can bind UN member states. Therefore Resolution 181 never could, and never purported to, convey sovereign title to any part of mandatory Pal estine to any party. ${ }^{21}$

Furthermore, the term "Jewish state" was actually a misnomer. In fact, the (misnamed) "Jewish state" would have had rough demographic parity between Jews and Arabs, under the terms of the Partition Plan, with a popuIation of 499,020 Jews and 509,780 Palestinian Arabs. ${ }^{22}$ Thus importantly, and contrary to popular belief, the Partition Resolution never proposed that Jews should constitute a demographic majority in the (misnamed) "Jewish state."

Finally, consistent with all the major legal instruments that had preceded it - i.e., the Balfour Declaration, the British $M$ andate for Palestine, and, of course, the Covenant of the League of $\mathrm{N}$ ations (which, as has al ready been discussed, is the cornerstone of the entire mandate enterprise and is, therefore, the most authentic and valid of the three instruments listed) - the Partition Resolution also contai- ned "savings clauses" that were intended to protect the rights of the indigenous Palestinian inhabitants in the geographical area that was proposed for the (misnamed) "Jewish state." ${ }^{23}$ Failure by the General Assembly to include such "savings clauses" would have run directly counter to the principles of equal rights and non-discrimination which featured so prominently in Articles 1(2) and 1(3) of the 1945 Charter of the United Nations, by which all members states of the United Nations were bound. (The relevance of the UN Charter to the final acts of the drama played out in Pal estine is discussed below, in Section IV.)

\section{U pon Reconsideration, the U.S. Backtracks on \\ "Partition": Trusteeship Is Proposed}

As soon as the General Assembly passed the Partition Resolution in November 1947, violent unrest erupted in Palestine. The Jewish Agency, on behalf of the Yishuv, accepted the Partition Plan. Thelocal indigenous Pal estinian population (who comprised the overwhelming majority of inhabitants at that time) rejected it. In such a scenario, "partition" could only be imposed forcibly and against the will of the majority of inhabitants. TheYishuv opted to use force to try to impose partition.

The Yishuv apparently hoped to be able to create a state in which Jews would constitute a demographic majority a notion which ran expressly counter to the provisions of the Partition Plan (as discussed above). Benny M orris and other "revisionist" historians have meticulously documented - using material from the official I sraeli state archives that the various militias of the Yishuv embarked upon systematic and premeditated military campaigns in the early months of 1948 deliberately designed to depopulate Palestinian villages and urban centres in the geographic area that had been designated in the Partition Plan for the (misnamed) "Jewish state." ${ }^{24}$ As noted in endnotes 3 and 4, to the opening paragraphs of this article, some 300,000 Palestinians had been forcibly displaced from their homes of origin as a result of these military campaigns even before the provisional government of Israel unilaterally declared its independence on $14 \mathrm{M}$ ay 1948, which is when interstate hostilities broke out. By the time the armistice agreements were concluded in 1949, some three-quarters of a million Palestinian refugees had been forcibly displaced from their homes of origin in theterritory that would become thestate of Israel. These expulsions were the result of preplanned military campaigns that under today's rubric would likely be termed "ethnic cleansing," since they were designed to manipulate the ethnic demographic composition of what would become the state of Israel.

In the face of these violent disturbances, the United States itself quickly backtracked on the Partition Resolu- 
tion. The U .S. realized the legal and practical impossibility of dividing mandate Palestine into two states against the wishes of the local indigenous Palestinian population without resorting to bloodshed.

N otably, the State Department's Policy Planning Staff reported to the U.S. Secretary of State as early as 19 January 1948 that imposition of the partition plan by force would appear to violate the Palestinians' right to self-determination under international law. ${ }^{25}$ Regrettably, this same 19 January memo also expressly recommended that the U.S. administration deliberately block any attempt to submit the question of the legality vel non of partition to the International Court of Justice. ${ }^{26}$ Such a call had been made many times by UN delegates in the various UN debates leading up to the adoption of the General Assembly's Partition Resolution.

\section{The U.S. Submits Its Trusteeship Proposal to the UN Security Council - 19 March 1948}

On 19 M arch 1948, Warren Austin, the U.S. ambassador to the UN, announced to the UN Security Council that theU.S. - after viewing the factson the ground in Palestine(referring to the militia warfare then currently raging) - deemed "partition" of Palestine to be totally impossible to implement without resort to force of arms. ${ }^{27}$ Accordingly, the U.S. recommended to the Security Council that the General Assembly be asked to institute a provisional Trusteeship for the whole territory of mandate Pal estine, under which the two communities would live together under a single "Government of Palestine" until a mutually satisfactory final agreement could be achieved. Under the U.S.-proposed Trusteeship Agreement, the United Nations itself, acting through its Trusteeship Council established under Article 75 of the Charter of the United N ations, ${ }^{28}$ would have constituted the "Administering Authority for Palestine," thereby replacing Britain as the mandatory authority.

On $19 \mathrm{M}$ arch 1948, the U.S. circulated a summary of the main principles of the proposed Trusteeship Agreement to other members of the Security Council. These summarized principles were released to the public asa "digest" on 5 A pril 1948 and published in the press on 6 April 1948. The principles are reproduced as an Annex to a pamphlet dated 16 April 1948 that the Jewish Agency prepared for the special session of the General Assembly convened at the request of theU.S. to discuss the political future of Palestine (see below). ${ }^{29}$ The "digest" of principles comprise 15 points. ${ }^{30}$

The political and diplomatic whirlwind that the U.S. initiated on 19 March 1948 was like opening a Pandora's box. The U.S. had acted at the highest levels of the UN - as a permanent member of the Security Council - to call openly for a complete UN policy reversal on the idea of partition for Palestine. Most importantly, the U.S. was openly calling into question the legality of partition. The debate, outcry, and political fallout reverberated throughout the entire world. The diplomatic record - both from the UN internal records, and from the capitals of nations around the globe - is voluminous. ${ }^{31}$

\section{The Jewish Agency and Zionist Circles React with Alarm to Trusteeship}

The Jewish Agency reacted with extreme alarm to the Trusteeship proposal. Their opposition was quite openly based upon the perception that the proposed Trusteeship arrangement would have: (1) avoided partition;32 (2) instituted a democratic electoral form of government in Palestine (majority rule); 33 (3) resulted, in all probability, in the restriction of future immigration to Palestine; ${ }^{34}$ and (4) provided protection for local, indigenous landowners. ${ }^{35}$

\section{U.S. Internal Disagreement over Trusteeship: Legal vs. Pragmatic Considerations}

TheU.S. State Department - staffed with legal experts - was the strongest proponent of Trusteeship. In contrast, the executiveand congressional branches faced political pressures that weighed against Trusteeship. As the State Department saw it, sincepartition waslegally and pragmatically not possible, Trusteeship was a viablealternative that could buy time until a peaceful settlement of the conflict could be achieved. On the other hand, the White H ouse was facing a tough election that year and did not want to alienate that segment of U.S. domestic opinion that favoured partition. A series of opinion polls were taken in February 1948 in order to gauge domestic sensitivities on the issue. ${ }^{36}$ Weighing against the influence of domestic proponents of partition, there was a natural countervailing domestic reluctance to commit U.S. ground troops ${ }^{37}$ to Palestine to implement partition. Thus pragmatic military analysis reinforced the legal view that partition was unworkable. The State Department view - that Trusteeship was the most likely option to buy time until a peaceful (and therefore legal) resolution to the conflict could be found - won out.

As debate in the Security Council and on theU.S. domestic front swirled on, the clock was ticking. The British had announced unequivocally that they intended to withdraw as mandatory power by $15 \mathrm{M}$ ay 1948 and they had absolutely no intention of staying on, even in a newly transformed role as "Trusteeship Administrator." As already noted above, the militias of the Yishuv were engaged in a full-scale systematic campaign aimed at "pacifying" and depopulating Palestinian population centres in the area designated in the Partition Plan as being for the (misnamed) "Jewish 
State." The Jewish Agency madeno effort to hide the effects of the Yishuv militias' anti-Palestinian depopulation military campaigns and referred to their effects as support for the proposition that partition was al ready "irreversible." 38

The U .S. Submits I ts Trusteeship Proposal to a Special Session of the General Assembly, Convened to Discuss the Future of Palestine - 16 A pril 1948

On 1 April 1948, the Security Council, on U.S. urging, passed a resolution requesting the Secretary-General to convene a special session of the General Assembly to "consider further the question of the future government of Palestine," 39 and specifically its proposed trusteeship agreement. On 16 April 1948, the UN General Assembly convened in special session to discuss the U.S. proposal for a provisional trusteeship for Palestine.

It was at this 16 A pril 1948 special session of the General Assembly that the U.S. officially presented a more fleshedout version of the its proposed Trusteeship Agreement some forty-seven articles long. ${ }^{40}$

The U.S.-proposed Trusteeship Agreement had received input from a wide variety of domestic sources, primarily from the executive branch, including: the State Department, and in particular the Department of Near Eastern Affairs; the N ational Security Council; the Joint Chiefs of Staff; the Policy Planning Staff; and President Harry Truman himself, who gave official approval to the final version. ${ }^{41}$

Significantly, the Trusteeship for Palestine proposed by the U.S. would have established a secular, democratic trusteeship government with a bicameral legislature comprising a "Senate" and a "H ouse of Representatives." ${ }^{2}$ It also would have provided for an independent judiciary, including a "Supreme Court." ${ }^{33}$ The executive functions would have been carried out by a "Governor-General," 44 who would have been appointed by the UN Trusteeship Council. (More specific details of the U.S. draft Trusteeship Agreement are discussed in the next section, below.)

The General Assembly submitted the U.S.-proposed Trusteeship Agreement as a "working paper" to its "First Committee," charged with considering matters relating to "Disarmament and International Security." On 20 April 1948, at its $118^{\text {th }}$ meeting, the General Assembly's First Committee officially embarked upon debate of the U.S.proposed Trusteeship Agreement. At the $120^{\text {th }}$ meeting of the First Committee, on 21 A pril 1948, theU .S. introduced a resolution recommending referral of the U.S.-proposed Trusteeship Agreement to the General Assembly's Fourth Committee, charged with considering matters fallingunder the heading "Special Political and Decolonization" (including Trusteeship); however, this recommended was not adopted. Following a period of general debate, the First Committee decided at its $128^{\text {th }}$ meeting to embark upon a detailed discussion of the U.S.-proposed Trusteeship Agreement for Palestine, concentrating on a list of specific sub-topics. The First Committee was to meet a total of twenty-five times during the special session of the General Assembly convened to discuss the question of the future government of Pal estine. D uring the course of its work, the First Committee divided into two subcommittees, to deliberate upon specific aspects of the issue.

\section{The Clock Runs out on a Peaceful Transition from $M$ andate to Trusteeship}

As is plainly evident, time weighed heavily against adoption of the Trusteeship Agreement. With the British-announced withdrawal datefrom Palestine of 15 M ay 1948, the General Assembly had less than one month - from 20 April 1948 to devise a way to construct an entirely new system of government for Palestine, which would be considered an exceedingly short timetable even in today's digital environment. Furthermore, the intense militia warfare raging in Palestine did not whet the appetite of any member state of the U nited Nations to volunteer for peacekeeping duties in the area to help ensure a peaceful transition from mandate to Trusteeship. Theclock wasticking, and theY ishuv militias kept up the military pressure to try to impose partition by force.

In the critical weeks that followed, the discussions about Trusteeship ground on in General Assembly committee and subcommittee debates. M eanwhile, the militia warfare raged on, and the Security Council issued a string of resolutions calling for peace in the area. On 1 April 1948, the Security Council unanimously passed a resolution ${ }^{45}$ calling for a truce between the Yishuv and Palestinian Arab communities in Palestine. In similar fashion, Security Council Resolution 46 of 17 April 1948 likewise called for "the immediate cessation of acts of violence in Palestine, and [the] establish[ment of] conditions of peace and order in that country." ${ }^{46}$ Security Council Resolution 48 of 23 April 1948 followed up by establishing a truce commission in Palestine. ${ }^{47}$ Finally, on 14 M ay 1948, the General Assembly passed a resolution ${ }^{48}$ recommending the appointment of an official United Nations mediator in Palestine, to try to resolve the dispute between the Yishuv and the indigenous Palestinian population.

However, by 14 M ay 1948, the clock had finally run out. While discussion of the U S.-proposed Trusteeship Agreement had wound its complex way through numerous $\mathrm{Ge}-$ neral Assembly committee and subcommittee debates, no final agreement had been reached. M eanwhile, the Yishuv seized the initiative and unilaterally declared the inde- 
pendence of the (provisional) state of Israel on 14 May 1948 , one day before the British were officially scheduled to withdraw. Interstate hostilities broke out, and the chance for a peaceful transition from mandate to Trusteeship was lost forever.

TheUN Security Council reacted to Israel's 14 M ay 1948 unilateral declaration of independence by issuing a string of resolutions calling for truces and cessation of hostilities. ${ }^{49}$ It is clear from this response that the Security Council preferred a peaceful transition from mandate and not a violent partition of Palestine or forcible displacement of its habitual residents.

Thus, review of the historical record reveals that from a legal perspective, the UN Security Council, the highest policy-setting body for the U nited Nations, clearly rejected partition of Palestine, as proposed in Resolution 181. Rather, as early as M arch and April of 1948, the Security Council and the General Assembly were jointly engaged in seeking a peaceful transition from mandate to Trusteeship, for all of Palestine.

\section{The Trusteeship Agreement Itself}

Key Characteristics of the U.S.-Proposed Trusteeship Agreement

TheU .S.-proposed T rusteeship A greement for Palestinewas premised on several key legal concepts which today are recognized asforming thebedrock core of human rightslaw. This was in conformity both with the standards embedded in the 1945 Charter of the United Nations, as well as the Universal Declaration of Human Rights, which then currently being drafted and which was finally adopted a merenine months later by the General Assembly in December 1948. (Section IV, below, will addresstheinternational law aspects of the Trusteeship Agreement.)

Dueto limitations of space, it is not possibleto reproduce the entire text of theU U.S.-proposed Trusteeship Agreement here, nor is it necessary for purposes of this discussion. For interested readers, however, it is available on the internet. ${ }^{50}$ Rather, for purposes of this article, it is more useful to highlight the most important features of the U.S.-proposed Trusteeship Agreement. Six points are of particular importance. They are summarized below, with cross-references to their original sourcein the Trusteeship Agreement itself:

(1) Territorial Unity: Under Trusteeship, Palestine would not be partitioned into two states but instead would continue to exist as a single geographic and political entity under a new form of government called Trusteeship. (Trusteeship Agreement, Preamble and Article 5, "Territorial Integrity.") ${ }^{51}$

(2) "M ajority Rule" Democracy: The Trusteeship entity would follow a democratic system of government.
Specifically, the democratic principle of "majority rule," premised on "one person, one vote," would prevail. (Article 20, "Legislature," and "Article 21, "Elections to the Legislature.") ${ }^{52}$

(3) Equality under the Law for all Citizens: The Trusteeship Agreement proposed equality under the law for all its citizens. No dejurediscrimination whatsoever was contemplated, whether "positive" discrimination or "negative" discrimination. (Article 9, "Fundamental Human Rights and Freedoms, excerpted below. Also, Article 32, "Educational System and Cultural and Benevolent Institutions.") ${ }^{53}$

(4) Citizenship for All H abitual Residents of Palestine: No ethnic demographic manipulation of any kind was contemplated under Trusteeship. The Trusteeship for Pal estine was to be a government for all its citizens. Forcible displacement of habitual residents from Palestine and subsequent refusal to repatriate them was simply not even contemplated under the Trusteeship Agreement. Such actions simply could not be justified under the human rights protections incorporated into the Trusteeship Agreement. (See Article 8, on "Citizenship," reproduced in full be low.)

(5) Protection of Rights of Tenant Farmers: Specific provisions were included to protect the land rights of local, indigenous tenant farmers. (See Article 31, on "Land Policy," reproduced in full below.)

(6) Limited Immigration to Palestine: Immigration to Palestine was to be limited by quotas for a period of several years and would be limited by Palestine's absorptive capacity. (Article 29, "Immigration.") ${ }^{54}$

In viewing the relevance of the Trusteeship Agreement from the perspective of the Palestinian refugees who were forcibly displaced by the Yishuv militias and subsequently denied re-entry by the state of I srael, the Trusteeship Agreement's article on citizenship is perhaps the most significant (since Israel bases much of its legal argument against repatriation of the Palestinian refugees on grounds of "citizenship" 55 ):

Article 8. Citizenship

Without prejudice to the provisions of legislation which may subsequently be enacted in Palestine, the following categories of persons shall be regarded as citizens of Palestine:

(1) Persons resident in Palestineon 1 July 1947, who were not on that date nationals of any State outside of Pal estine;

(2) Persons resident in Palestine on 1 July 1947, who were nationals on that date of a State outside of Pal estine, if they have filed with the Government of Palestine at any time before 1 N ovember 1948 a declaration, in such form as may be provided 
by the Government of Palestine, that they renounce their former nationality in favour of Palestinian citizenship.

(3) Persons who have resided in Palestine for three months and who, while continuing to be residents of Pal estine, file with the Government of Palestine a declaration that they renounce the nationality of any State outside of Palestine of which they may be nationals, and take an oath of allegiance to the Government of Palestine;

(4) Children of Palestinian citizens, wherever born (provided such children have not at birth or subsequently acquired the national ity of a State outside of Palestine). [emphasis added] ${ }^{56}$

In viewing the relevance of the Trusteeship Agreement from the perspective of the Palestinian refugees whose entirelandholdings and property were subsequently confiscated by the state of Israel and turned over for exclusive use by Jewish citizens of the state of Israel, ${ }^{57}$ the Trusteeship Agreement's nine clauses on "Fundamental H uman Rights and Freedoms" - of which clauses (2), (3), and (5) aremost relevant to the issue of non-discrimination with respect to property rights - are also extremely important:

\section{Article 9. Fundamental H uman Rights and Freedoms}

...

Article 9(2): N o discrimination of any kind on grounds of race, religion, language or sex shall be made against any person in Palestine.

Article 9(3): All persons in Palestine shall be entitled to equal protection of the laws.

...

Article 9(5): No person or property within Palestine shall be subject to search or seizure except according to legal process. ${ }^{58}$ Concerning the protection of the land rights of local, indigenous farmers, the Trusteeship Agreement contained Article 31, titled "Land Policy," which read as follows:

\section{Article 31. Land Policy}

1. The Governor-General shall establish and maintain a land system appropriateto theneeds of Palestine, in which there shall beno limitation on the sale, purchase, lease or use of land which discriminates on grounds of race, nationality, community or creed. H owever, under the authority of the Governor-General, adequate measures shall be taken to assure protection for the interests of small owners or tenants in cases of transfer of arable or grazing lands.

2. TheGovernor-General shall appoint a commission of impartial experts, who shall be neither Arab nor Jew, to recommend the criteria upon which the land system described in paragraph 1 shall be based. ${ }^{59}$

Thus the governmental model suggested by the U.S. in its proposed Trusteeship Agreement envisioned the creation through peaceful means of a secular, democratic govern- ment in all of Palestine whose entire community of inhabitants would have enjoyed full equality under the law.

\section{The Trusteeship Agreement Viewed in Light of International Law}

The Legal Principles of "Trust" and Fiduciary Duties of the "T rustee" Were Continued from the M andate Concept and Expanded into Trusteeship

Thenotion of "trust" that was well-enough developed under the Covenant of the League of Nations mandate system received even greater emphasis under the proposed Trusteeship system.

The U nited $\mathrm{N}$ ations trusteeship system was set up under Chapter XII and XIII of the Charter of the U nited Nations, which provide for UN supervision and administration of certain territories placed under thetrusteeship regime. Under Article 77 of the Charter, it was envisioned that former League of $\mathrm{N}$ ations mandates that had not terminated by the dissolution of the League of Nations, in 1946, would naturally come within the trusteeship system. ${ }^{60} \mathrm{H}$ owever, the process was not automatic, since the consent of the administering state was required under Article 79 of the Charter.

Under the new UN 's new trusteeship system, Article 73 of the UN Charter unambiguously stated that "the interests of theinhabitants of these [trust] territories areparamount" [emphasis added]. ${ }^{61}$ The inhabitants of the territories were clearly the intended "beneficiaries" of the trusteeship system, and, accordingly, the "fiduciary" obligations of the administering "trustee" authorities were made stricter.

Among the "basic objectives" of the Trusteeship system as stated in Article 76 of the UN Charter are:

Article 76(b): to promote the political, economic, social and educational advancement of theinhabitants of the trust territories, and their progressive development towards self-government or independence as may be appropriate to the particular circumstances of each territory and its peoples and the freely expressed wishes of the peoples concerned...

Article 76(c): to encourage respect for human rights and for fundamental freedoms for all without distinctions as to race, sex, language, or religion.... [emphasis added]. ${ }^{62}$

It must be noted that the $U \mathrm{~N}$ has achieved a fairly good track record as far as securing the eventual independence of all the other "Class A" mandates (apart from Palestine), as well as all the other "Class B" and "Class C" mandates that were transformed into U N trusteeships. As has already been noted, above, all four of the other "Class A" mandates had al ready achi eved full independence by the end of W orld War II, so there was no need to transform any of them into U N trusteeships. N otably, of the other "Class B" and "Class 
C" mandatesthat wereconverted to UN trusteeships, all did gain self-government and independence under international supervision. ${ }^{63}$

Thus Palestine is the clear exception to the established pattern. The fact that Palestine did not convert to Trusteeship and eventually achieve independence indicates that the League of Nations' and UN's intended goals and purposes were subverted.

\section{Trusteeship Viewed under International Law: UN Charter N orms}

There are three primary norms of the Charter of the United Nations that are particularly relevant to analysis of the U.S.proposed Trusteeship Agreement for Palestine. All three are found in Article 1 of theCharter, which states thefundamental "purposes" of the U nited $N$ ations.

The first principleis equality under thelaw, which has as its corollary the prohibition against discrimination. This principle is stated in two places: Article 1(2) ${ }^{64}$ and Article 1(3). ${ }^{65}$ The second principle is self-determination of peoples. This principle is stated in Article 1(2). ${ }^{66}$ These purposes are repeated in Articles $55^{67}$ and $56^{68}$ of the Charter.

The third principle is the prohibition against aggression, and its corollary, the inadmissibility of the acquisition of territory by force. This principle is stated in Article 1(1). ${ }^{69}$ This third principle receives reinforcement from Article 2 of the Charter, which states how M ember States will act to achieve the purposes stated in Article $1 .^{70}$

$\mathrm{H}$ aving already examined previously in this article the sharp differences in outcome between partition and Trusteeship, it seems rather self-evident that partition violated all three of the above-stated principles. Trusteeship, on the other hand, held out the possibility of conforming with all three of the above-stated principles.

Furthermore, Article 76 of the Charter, as was discussed in the preceding section, spells out the specific purposes of theUN Trusteeship system itself. The two principles which are most relevant to analysis of the U.S.-proposed Trusteeship for Palestine include promotion of "self-government or independence" of peoples, stated in Article 76(b), and respect for "human rights" and "fundamental free doms," stated in Article 76(c).

It is therefore noteworthy that the U.S.-proposed Trusteeship Agreement for Palestine specifically concluded with Article 47, on "Termination of Trusteeship." This article specifically laid out the "road map" to independence for Palestine, even though no specific timetable was given. ${ }^{71}$ Therefore, on this point as well, the Trusteeship is much more in conformity with Charter norms that partition.

Finally, Article $80^{72}$ of the Charter of the U nited Nations specifically stated that the $U N$, as successor organization to the League of $\mathrm{N}$ ations, did not have the legal capacity to alter to the detriment of indigenouspeoples any obligations that had been made to them by its predecessor organization, the League of Nations. Consequently, any attempt by the UN to alter the terms of the Palestine $M$ andate to the detriment of the Palestinian people (which the Partition Plan clearly proposed doing) would be contrary to the Charter of the United Nations. Once again, Trusteeship proves to be the model more in conformity with the purpose and goals of the United Nations than partition.

Trusteeship Viewed under International Law: The Universal Declaration of Human Rights

The U S.-proposed Trusteeship Agreement - and most importantly, its very significant differences from the General Assembly's Partition Plan, which had preceded it - must be read in light of the fact that during that exact same period (1947-48), one of the most important human rights instruments ever drafted - the Universal Declaration of Human Rights $^{73}$ (hereinafter UDHR) - was being prepared and reviewed by the UN General Assembly. The Trusteeship Agreement itself incorporates certain fundamental human rightsnorms that were included in the UDHR and which are viewed today as forming the bedrock core of human rights law.

The UDHR was drafted in two years, between January 1947 and December 1948. TheU N Commission on Human Rights supervised the drafting process, including theincorporation of comments from $M$ ember States of the UN, before submitting the draft text to the General Assembly. The General Assembly reviewed the UDHR draft text very thoroughly, with the fifty-eight $\mathrm{M}$ ember States voting a total of 1,400 times on virtually every word and every clause of the text. In theend, theUDH R was adopted unanimously by the General Assembly on 10 December 1948 (with eight abstentions). ${ }^{74}$

The UDH R contains many provisions which are relevant to the events of 1948 and the forcible displacement of habitual residents of Palestine (and Israel's subsequent refusal to repatriate them). The Trusteeship proposal, if adopted, could have avoided the phenomenon of forcible displacement and refusal to repatriate. The articles of the UDHR that are most relevant to the 1948 fact-pattern include the following:

Article 13:

(1) Everyone has the right to freedom of movement and residence within the borders of each State.

(2) Everyone has the right to leave any country, including his own, and to return to his own country. 
Article9: No oneshall besubjected to arbitrary arrest, detention or exile.

Article 15:

(1) Everyone has the right to a nationality.

(2) No one shall be arbitrarily deprived of his nationality nor denied the right to change his nationality.

Article 17:

(1) Everyone has the right to own property alone as well as in association with others.

(2) No one shall be arbitrarily deprived of his property.

Article 21:

(1) Everyone has the right to take part in the government of his country, directly or through freely chosen representatives.

...

(3) The will of the people shall be the basis of the authority of government; this will shall be expressed in periodic and genuine elections which shall be by universal and equal suffrage and shall be held by secret vote or by equivalent free voting procedures.

Article 29:

$\cdots$

(2) In the exercise of his rights and freedoms, everyone shall be subject only to such limitations as are determined by law solely for the purpose of securing due recognition and respect for the rights and freedoms of others and of meeting the just requirements of morality, public order and the general welfare in a democratic society.

(3) These rights and freedoms may in no case be exercised contrary to the purposes and principles of the U nited Nations.

Article 30: Nothing in this Declaration may be interpreted as implying for any State, group or person any right to engage in any activity or to perform any act aimed at the destruction of any of the rights and freedoms set forth herein.

Article 7: All are equal before the law and are entitled without any discrimination to equal protection of the law. All are entitled to equal protection against any discrimination in violation of this Declaration and against any incitement to such discrimination.

Article 2: Everyone is entitled to all the rights and freedoms set forth in this Declaration, without distinction of any kind, such as race, colour, sex, language, religion, political or other opinion, national or social origin, property, birth or other status. "Furthermore, no distinction shall bemadeon thebasis of political, jurisdictional or international status of the country or territory to which a person belongs, whether it be independent, trust, nonselfgoverning or under any other limitation of sovereignty." [emphasis added] $^{75}$

\section{Conclusion}

In conclusion, the legal value of the U.S.-proposed Trusteeship Agreement must be viewed in the international law context in which it was drafted.

First, the U.S. Trusteeship Agreement succeeded to, and expanded upon, the concept of "trust" and "trusteeship" that it had inherited from the League of Nations' mandate system. Thus Britain had fiduciary duties to the local, indigenous population of Palestine, which were breached. It was the responsibility of the international community to remedy this breach. The Trusteeship Agreement held the potential to remedy that breach. It held out the very real possibility of forestalling the outbreak of interstate violence on $15 \mathrm{M}$ ay 1948 and of bringing about a peaceful transition from mandate to Trusteeship in Palestine. For thesereasons alone, it should have been adopted.

Second, the Trusteeship Agreement conformed with important norms of international law that had been enshrined in the Charter of the United Nations, as well as in the UDHR, which was well into the final drafting stages when the U.S. proposed Trusteeship for Pal estine and was passed a mere nine months later. Compared to the crude Partition Plan proposed by the General Assembly - which blatantly violated fundamental norms of both the Charter and the UDHR -theU .S.-proposed Trusteeship agreement conformed exceptionally much better with the fundamental norms expressed in both documents. It is indisputable that the norms of the Charter were binding upon all states at the time. The norms of the UDHR were, if not binding in a technical sense, at least evidence of a growing consensus that states should respect human rights and not abusethem, and especially not on a mass scale.

In conclusion, the U.S.-proposed Trusteeship Agreement had the potential to avoid or reverse the mass forcible displacement of Palestinian refugees in 1948 and Israel's subsequent refusal to repatriate them. Fifty-four years of forcible displacement and exile might have been avoided for one of the world's largest and longest-standing refugee population groups. It is to be regretted that this peaceful transformation of Palestine to Trusteeship was subverted.

Perhaps, however, the Trusteeship Agreement can serve as a guidepost for a peaceful future solution for the Palestinian refugees, one where habitual residents are allowed to choose the option of voluntary return to their homes of origin, even after a fifty-four-year absence, and one where government is designed to be for the benefit of all its citizens. The value of the Trusteeship Agreement in the context of the current search for a negotiated settlement between the Israelis and Palestinians is that it conformed with fundamental norms of the UN Charter and emerging human rights law that were recognized to exist in 1948. It 
not only conformed with these norms but it serves as an important historical confirmation and evidence of the existence of these norms. These norms have only been strengthened in the intervening passage of time since 1948. Thus these norms could, and logically should, be used as basel ine starting points if one were proposing to undertake the design of a legal settlement of the Palestinian refugee question that would conform with international law.

\section{Notes}

1. "Draft Trusteeship Agreement for Palestine: Working Paper Circulated by the United States Delegation," UN Doc. A/C.1/277 (1948), appearing in Official Records of the Second Special Session of the General Assembly, Annex to Volumes I and II (1948); also available on the UNISPAL website [hereinafter "Trustee Agreement"].

2. It is estimated that at least 700,000 Palestinian refugees were externally displaced during the 1948-related conflict, while higher-end estimates place the figure for the initial group of 1948 Palestinian refugees as approaching 1 million. See, e.g., General ProgressReport and Supplementary Report of theU nited Nations Conciliation Commission for Palestine, Covering the Period from 11 D ecember 1949 to 230 ctober 1950, UN GAOR, $5^{\text {th }}$ Sess., Supp. N o. 18, U.N. D oc. A/1367/Rev. 1 (23 October 1950) (Appendix 4 of which, titled "Report of the Technical Committee on Refugees," which was submitted to the Conciliation Commission in Lausanne on 7 September 1949, listed an estimated figure of 711,000 for the "refugees from I sraelcontrolled territory," a figure which theT echnical Committee stated it "believed to be as accurate as circumstances permit"). See also J. Abu-Lughod, "The Demographic Transformation of Palestine," in I. Abu-Lughod, ed., The Transformation of Palestine: Essays on the O rigin and D evelopment of the Arab-Israeli Conflict (Evanston: N orthwestern U niversity Press, 1971) 139, 161 (an estimated 780,000 displaced Palestinians were trapped outsidewhat becamethe 1949 armisticelinesand were not allowed to return); I. Pappé, "Were They Expelled?: The $\mathrm{H}$ istory, $\mathrm{H}$ istoriography and Relevance of the Palestinian Refugee Problem," in G. Karmi and E. Cotran, eds., The Palestinian Exodus 1948-1998 (Reading: Ithaca Press, 1999) at 52 (noting that some demographers put the figure of externally displaced Palestinians from this period at as high as one million persons).

3. It is estimated by reliable sources that by $14 \mathrm{M}$ ay 1948 (when Israel unilaterally declared its independence) an estimated 300,000 Pal estinian refugees had al ready been forcibly displaced from their homes of origin dueto systematic Yishuv militia attacks. See, e.g., B. M orris, "The Causes and Character of the Arab Exodus from Palestine: The I sraeli D efense Forces Intelligence Branch Analysis of June 1948" (1986) 22 M iddle Eastern Studies 5, 6-7; E. B. Childers, "The Wordless Wish: From Citizensto Refugees," in I. Abu-Lughod, ed., supra note2, 165, 193; M. A kehurst, "The Arab-I sraeli Conflict in International Law" (1973) 5 N ew Zealand U niversity Law Review 231, 233.
4. Charter of the U nited N ations, 26 J une 1945, 59 Stat. 1031, T.S. 993, 3 Bevans 1153, entered into force Oct. 24, 1945, art. 75 [hereinafter "Charter of the United Nations"].

5. This principle of electoral democracy is now termed "internal self-determination" by some international law scholars. See, e.g., D. Raic, Statehood and the Law of Self-D etermination (The Hague, London, and New York: Kluwer Law International, 2002).

6. Covenant of the League of N ations, 28 June 1919, reprinted in $H$. Cattan, Palestine and International Law: The Legal Aspects of the Arab-Israeli Conflict (London: Longman, 1973) 259 [hereinafter "Covenant of the League of Nations"].

7. See, generally, League of $\mathrm{N}$ ations, TheM andates System: O rigin - Principles - Application (Geneva: League of Nations Publications, 1945).

8. "Covenant of the League of N ations," supra note 6, art. 22(4).

9. See, e.g., A.N. Yiannopoulos, "Property," in Clark and Ansay, eds., Introduction to the Law of the U nited States.

10. See, e.g., J. Quigley, Pal estineand I srael: A Challenge to Justice (Durham and London: Duke University Press, 1990), 15 and n. 5, citing H. D. Hall, Mandates, Dependencies, and Trusteeships (London: Stevens for the Carnegie Endowment for International Peace, 1948) 81 ("The League of Nations' Permanent $\mathrm{M}$ andates Commission, which oversaw mandate administration, said that mandatory powers had no right of sovereignty but that the people under the mandate held ultimate sovereignty").

11. See, e.g., Q. Wright, $M$ andates U nder the League of $\mathrm{N}$ ations (Chicago: University of Chicago Press, 1930) at 535 (stating that both the League of Nations and the mandatory authority are "joint trustees" with fiduciary duties toward the inhabitants of themandated territory, by anal ogy "to the conception of trust in Anglo-American law").

12. See N. Feinberg, Some Problems of the Palestine $M$ andate (Tel A viv, Pal estine: Shoshani's Printing Co., 1936) at 90 (“W ehave seen that Palestine is not mentioned by name in Paragraph 4 [ of Article22 of the Covenant]. That Paragraph relates only to 'certain communities formerly belonging to the Turkish Empire', - certain but not all communities'.").

13. Balfour Declaration," letter from Arthur James Balfour (then Britain's Foreign Secretary) to Lord Rothschild dated 2 November 1917, reproduced asafrontispiecein L. Stein, TheBalfour Dedaration (London: Vallentine, M itchel \& Co., 1961).

14. Id.

15. "M andate for Palestine," (1922) 80 fficial Journal (League of $\mathrm{N}$ ations) 1007; also in Terms of League of $\mathrm{Nations} M$ andates: Republished by the United Nations, UN Doc. A/70 (1946), reprinted from Permanent M andates Commission No. 466, League of Nations Doc. C.529.M .314.1922.VI; also available on the UNISPAL website [hereinafter "British Mandate for Palestine"].

16. See, e.g., N. Feinberg, supra note 12 at 73 (discussing a petition submitted to the League of Nations' Mandates Commission by the Pal estine Arab Women Congress in 1932 in which they "claimed self-government in order to obtain theabrogation of 
the Balfour Declaration, the abolition of the $M$ andate and the establishment of a national government with a view to attaining completeindependencewithin an Arab Federation"; and discussing also the decision of the $M$ andates Commission not even to comment publicly on the proposal of establishing a [democratic electoral] Legislative Council in mandate Palestine due to the volatile political situation there).

17. See "British M andatefor Palestine," supra note 15. TheBritish $M$ andate contained thefollowing numerous "savings clauses": (1) second preambular paragraph (repeating the "savings clause" of the Balfour Declaration); (2) Article 2 ("The Mandatory shall be responsible for ... the development of self-governing institutions, and also for safeguarding the civil and religious rights of all the inhabitants of Palestine, irrespective of race and religion"); (3) Article 5 ("The M andatory shall be responsiblefor seeing that no Palestineterritory shall beceded or leased to, or in any way placed under the control of, the Government of any foreign Power"); (4) Article 6 ("The Administration of Palestine, while ensuring that the rights and position of other sections of the population are not prejudiced... "); (5) Article 9 ("The M andatory shall be responsible for seeing that the judicial system established in Palestine shall assure to foreigners, as well as to natives, a completeguarantee of their rights. Respect for the personal status of the various peoplesand communities and for their religious interests shall befully guaranteed. In particular, the control and administration of Wakfs [ religious charitable trusts] shall beexercised in accordance with religious law and the dispositions of the founders."); (6) Article 11 ("The Administration of Palestine shall take all necessary measures to safeguard the interests of the community in connection with the development of the country... "); (7) Article 15 ("The Mandatory shall see that complete freedom of conscience and the free exercise of all forms of worship, subject only to the maintenance of public order and morals, are ensured to all. No discrimination of any kind shall be made between the inhabitants of Palestine on the ground of race, religion or language. No person shall beexcluded from Palestine on the sole ground of his religious belief."); (8) Article 16 ("The M andatory shall beresponsiblefor exercising such supervision over religious or eleemosynary bodies of all faiths in Palestine as may be required for the maintenance of public order and good government. Subject to such supervision, no measures shall be taken in Palestine to obstruct or interfere with the enterprise of such bodies or to discriminate against any representative or member of them on the ground of his religion or nationality."); (9) Article22 ("English, Arabic and Hebrew shall be the official languages of Palestine. Any statement or inscription in Arabic on stamps or money in Palestine shall be repeated in Hebrew and any statement or inscription in H ebrew shall be repeated in Arabic."); and (10) Article 23 ("The Administration of Palestine shall recognise the holy days of the respective communities in Palestine as legal days of rest for the members of such communities.") [emphasis added].
18. GA Res. 181, UN GAOR, 2 d Sess., UN Doc. A/519 (1947) (resolution of 29 N ovember 1947, recommending partition of Palestine) [hereinafter "Partition Resolution"].

19. As has been well documented, J ews only owned 6 per cent of theland in M andate Pal estineand only constituted 30 per cent of the population in themandate area at the timethePartition Resolution was passed. H owever, the Partition Plan nevertheless would have allotted 56 per cent of theterritory of $M$ andate Palestine to the (misnamed) "Jewish state." The Palestinian Arabs, who constituted 70 per cent of the population and who owned or on whose behalf the remaining 94 per cent of the land was being administered through the "Class A" status of the Palestine $\mathrm{M}$ andate established by the League of Nations, felt that the partition proposal was fundamentally unfair to them. The land ownership and demographic statistics are given in the Report of Sub-Committee 2 to the Ad H oc Committee on the Palestinian Question, GAOR,, $2 d$ sess., UN Doc. A/AC.14/32, November 11, 1947, Appendix I, "Estimated Population of Palestine as at 31 December 1946," 304 [hereinafter "UN Land and Demographic Statistics"].

20. "Charter of the United Nations," supra note 4, art. 10 ("The General Assembly... may make recommendations to the $M$ embers of the United Nations or to the Security Council or to both...."); art. 11 १ 1 ("TheGeneral Assembly ... may make recommendations ... to theM embers or to the Security Council or both") ; art. 11 १ 2 ( "The General Assembly ... may make recommendations with regard to any such questions to the state or states concerned or to the Security Council or to both... ."); art. 14 (“... the General Assembly may recommend measures for the peaceful adjustment of any situation, regardless of origin, which it deems likely to impair the general welfare or friendly relations among nations... .").

21. On 24 February 1948, the U.S. representative stated in a Security Council debate on Resolution 181 the U.S. view that UN General Assembly resolutions are recommendatory and have "moral force" only, but cannot be considered legally binding. Therefore, the U.S. representative stated, the UN Charter "does not empower the Security Council to enforce a political settlement made pursuant to a recommendation of the General Assembly." U N SCOR, 3d year, 253d mtg., p. 267, February 24, 1948, UN Doc. S/PV/253 (1948).

22. See "UN Land and Demographic Statistics," supra note 19, at 304.

23. See "Partition Resolution," supra note 18, which contains the following "savings clauses":

Part I, Section B "Steps Preparatory to Independence," Paragraph 10: The Constituent Assembly of each Stateshall draft a democratic constitution for its State and choose a provisi onal government... The Constitutions of the States shall embody Chapters 1 and 2 of the Declaration provided for in section $\mathrm{C}$ below [Chapter 1 being on "Holy Places, Religious Buildings and Sites" and Chapter 2 being on "Religious and M inority Rights"] and include, inter alia, provisions for: (a) Establishing in each State a legislative body elected by universal suffrage and by secret ballot on 
the basis of proportional representation... (d) Guaranteeing to all persons equal and non-discriminatory rights in civil, political, economic and religious matters and theenjoyment of human rights and fundamental freedoms, including freedom of religion, language, speech and publication, education, assembly and association.);

Part I, Section C "Declaration," "General Provisions": "The stipulations contained in the Declaration are recognized as fundamental laws of the State and no law, regulation or official action shall conflict or interfere with these stipulations, nor shall any law, regulation or official action prevail over them.

Part I, Section C "Declaration," Chapter 2 "Religious and M inority Rights":

(1) Freedom of conscienceand thefree exercise of all forms of worship, subject only to the maintenance of public order and morals, shall be ensured to all.

(2) No discrimination of any kind shall be made between the inhabitants on the ground of race, religion, language or sex.

(3) All persons within the jurisdiction of the State shall be entitled to equal protection of the laws.

(4) The family law and personal status of the various minorities and their religious interests, including endowments, shall be respected.

(5) Except as may berequired for the maintenance of public order and good government, no measure shall be taken to obstruct or interfere with the enterprise of religious or charitable bodies of all faiths or to discriminate against any representative or member of these bodies on the ground of his religion or nationality.

....

(8) No expropriation of land owned by an Arab in the Jewish State (by a Jew in the Arab State) shall be allowed except for public purposes. In all cases of expropriation full compensation as fixed by the Supreme Court shall be paid previous to dispossession.

Part I, Section C "Declaration," Chapter 3 "Citizenship, International Conventions and Financial O bligations":

(1) Citizenship: Palestinian citizens residing in Palestine outside the City of Jerusalem, as well as Arabs and Jews who, not holding Palestinian citizenship, residein Palestine outsi dethe City of J erusalem shall, upon the recognition of independence, become citizens of the State in which they are resident and enjoy full civil and political rights. Persons over the age of eighteen years may opt, within one year from the date of recognition of independence of the State in which they reside, for citizenship of the other State, providing that no Arab residing in thearea of theproposed Arab Stateshall have the right to opt for citizenship in the proposed J ewish State and no J ew residing in the proposed Jewish Stateshall have the right to opt for citizenship in the proposed Arab State. The exercise of this right of option will be taken to include the wives and children under eighteen years of age of persons so opting... .[emphasis added].

24. See, e.g., B. M orris, The Birth of the Palestinian Refugee Problem, 1947-1949 (Cambridge: Cambridge University Press, 1987).

25. "Report by thePolicy Planning Staff on Position of the U nited States with Respect to Palestine, January 19, 1948" (1976) 5 Foreign Relations of the U nited States 1948546 at 549, 553. Michael Cohen reports that "George Kennan, head of the recently formed Policy Planning Staff, observed that the United $N$ ations had not clarified certain problems concerning the legality of partition [emphasis added]," citing a 19 January 1948 memorandum by Kennan on thistopic. See M. J. Cohen, Palestine and the Great Powers: 1945-1948 (Princeton, New Jersey: Princeton University Press, 1982) at 346 [hereinafter "Palestine and the Great Powers"]

26. Paragraph 33 of the (top secret) 19 J anuary 1948 Policy Planning Staff memo reads: "We [the U.S. government] should oppose referring to the International Court [of Justice] the question of the U.N. recommendation on Palestine on the grounds that the fundamental issue, i.e., whether the two communities involved will cooperate to make the partition plan effective, is not a proper question for the Court." See M . J. Cohen, ed., The American Trusteeship Proposal 1948, vol. 38 in a series titled "The Rise of Israel: A Documentary Record from the Nineteenth Century to 1948 - A Facsimile Series" (New York \& London: Garland Publishing, 1987) at 22 [hereinafter "American Trusteeship Proposal"]. It should be noted here that the proper question to have been submitted to the International Court of Justice was not "whether the two communities would have cooperated" with partition, but rather "whether partition itself was legal under international law." The first formulation is a question of mere speculation, upon which the court would not likely have passed judgment anyway. The second formulation is an important question of international law, which should have been heard by a competent adjudicator.

27. Foreign Relations of the U nited States 1948 , vol. 5, p. 801 (1976). UN SCOR, $3^{\text {rd }}$ year, $271^{\text {st }}$ mtg., 19 March 1948, UN Doc. S/PV.271, 31; N ew York Times (20 M arch 1948) A2.

28. "Charter of the U nited Nations," supra note 4, art. 75.

29. See The Jewish Agency for Palestine, M emorandum on Trusteeship for Palestine: Observations on a Temporary Trusteeship for Palestine as Proposed by the U nited States (April 5, 1948) (submitted to thespecial sessions of the UN General Assembly convened at the recommendation of the U.S. to discuss the political future of Palestine on 16 April 1948) [hereinafter "Jewish Agency M emorandum"].

30. Id. Following is the text of the fifteen points contained in the "Digest":

Digest of U nited States Trusteeship Plan as Released to the Press and Published A pril 6 [1948]:

(1) A temporary trusteeship agreement for Palestineshould bewithout prejudice to the rights, claims or position of the 
parties concerned or to the character of the eventual political settlement.

(2) The agreement should be of indefinite duration. However, it should be subject to prompt termination whenever the Arab and Jewish communities of Palestine agree on the future government of their country.

(3) The trusteeship agreement might designate the U nited $\mathrm{N}$ ations itself as the administering authority, and the responsibility for this should be placed in the Trusteeship Council of the United $\mathrm{N}$ ations. Administrative, legislative and judicial powers, should beexercised in Palestinethrough a separate body called "the Government of Palestine."

(4) The temporary trusteeship agreement could include many of the features al ready devel oped by the Trusteeship Council for its draft statute for the proposed International Territory of Jerusalem.

(5) The Government of Palestine should be headed by a Governor $\mathrm{G}$ eneral who would beappointed by and responsible to the Trusteeship Council.

(6) The Government of Palestine should include a cabinet and a democratically elected legis lature, preferably bi-cameral. (7) The trusteeship agreement should provide for the maintenance of law and order within Palestine. The Government of Palestine should be responsible for law and order within Palestine through its locally recruited policy and volunteer forces under Article 84 of the Charter of the United N ations.

When the forces of the Government of Palestine are insufficient for this purpose, then the Governor General should be authorized to call upon such states as would be specified in the agreement to assist in the maintenance of security in Palestine. A separate protocol to the trusteeship agreement would be concluded which would contain an undertaking by those named to accept the responsi bility on specified conditions.

(8) The Government of Palestine should be enabled under the agreement to take over on a temporary basis existing arrangements in Palestinepending the establishment of the organs specified in the agreement.

(9) The agreement should make specified provisions for immigration and land purchase. This should be negotiated in consultation with representatives of the ewish and A rab communities.

(10) The standard of living in the public services under the temporary trusteeship should be such as to be supported by the resources of Palestine itself, and large United Nations subsidies should not be expected.

(11) The expenditures which arise in connection with the employment of forces of members of the U nited Nations to assist in the defense of Palestine and the maintenance of law and order should be defrayed by those members who are supplying the forces.

(12) The U nited Nations itself should pay the salaries of the principal officials, such as the Governor General and Chief Justice, and possibly others.
(13) Should the General Assembly on therecommendation of the Trusteeship Council believe that it was necessary to raise funds in addition to those required for normal purposes by the Palestine Government, these additional funds should be supplied as subsidies, or as recoverable loans from the United Nations. These would be advanced on the same basis as contributions to the budget. Such a Palestine budget should be handled by the United Nations as a separate budget.

(14) The trusteeship agreement should contain adequate guarantees for the safeguarding of the holy places.

(15) The temporary trusteeship should terminate as soon as a majority of the members of each of the two principal communitiesin Palestinehasagreed upon a plan of government. The Governor General should take all steps possible to bring about such an agreement.

31. See, e.g., Palestine and the Great Powers, supra note 25 , and especially Chapter 13; American Trusteeship Proposal, supra note 26; U nited N ations, Y earbook of the U nited N ations 19471948 (N ew York: UN Dept. of Public Information, 1948), also available in excerpted form on the UNISPAL website.

32. See "Jewish Agency Memorandum," supra note 29, Paragraphs 12-14.

33. See "J ewish Agency M emorandum," supra note 29 at 9 , containing the Jewish Agency's comments on the notion of electoral democracy:

The provision for a "democratically elected legislature" is thegravest feature of the entire[Trusteeship] proposal, and raises disquieting questions as to its intentions. This provision appears to involve the application of majority rule to Palestine as a whole, and to ignore the dual character of its national composition. The most widely accepted principlein the Palestine question is theirrelevance of formal democracy, based on majority domination, to a country composed of two separate nations which do not hold the ends of life in common or agree on the central purposes of the state. In such conditions, to apply democracy to the population as a wholeis to deny it to the ews entirely, by subjecting them to minority status. Theessence of thePalestinequestion lies in the need to apply self-determination not to a fictitious single entity, but to the two separate groups, so that each is free and sovereign within the widest limits compatible with the freedom and sovereignty of theother. [Emphasis added.]

34. See "Jewish Agency M emorandum," supra note 29 at 12 . The Jewish Agency noted that theTrusteeship'sproposed principle of majority rule logically "must operate against the authorization of any substantial immigration or land purchase by Jews." The Jewish Agency viewed this with alarm, due to the "inseparable connection between the concepts of Jewish statehood and Jewish immigration."

35. Id.

36. See Palestineand the G reat Powers, supra note 25 at 350.

37. In late January 1948, U.S. Col. Harold H oskins warned "that if the U nited States helped implement partition, either indirectly, or with itsown troops, MiddleEastoil suppliesto theW est would 
be cut drastically, and its action might 'without exaggeration, be the spark that lights the fire of World War Three'," cited in Palestine and the Great Powers, supra note 25 at 348.

38. See "Jewish A gency M emorandum," supra note29. Paragraph 13 of the memorandum describes the "spectacular impetus to this partition tendency" which occurred in Palestine since 29 November as a process of British withdrawal from "certain zones" and J ewish "assertion of authority" in thosezones. The Memorandum, which is addressed to the United Nations, naturally does not go into detail regarding the practices of the Yishuv militias' military campaigns against Palestinian population centres - which have been so aptly documented by Israeli historian Benny Morris, among others - but instead refers to the results of those campaigns:

13.The disintegration of the $\mathrm{M}$ andatory regime since $\mathrm{N}$ ovember 29 has given a spectacular impetus to this partition tendency, both in its functional and its territorial aspects. As the $M$ andatory relinquishes an essential governmental service in the Jewish area, the Jews begin to operate it. As the $M$ andatory virtually evacuates a certain zone, Jewish authority asserts itself. There are large populated areas of the country, both Jewish and Arab, in which the writ of the central administration does not run at all. The degree to which this process had developed can best be appreciated from the fact that the J ews themselves exercise full responsibility in their community for the most vital governmental function - that of defence. M eanwhilean existing tendency of J ewish autonomy has been accentuated in every field. In the coming days and weeks the $M$ andatory's disintegration will leave a widening vacuum in food supplies, communications, postal and telegraphic services, currency, police, etc., etc. The Jews, anticipating chaos, have worked out plans and prepared machinery to assure continuity and order in the daily routine of life. The entire Jewish population reposes its trust and obedience not in any central government of the entire country, but in its own authorities, on the understanding that they will set up theadministration for the J ewish State area. The provisional J ewish authorities arealready endowed with that effectiveinternal recognition which is the most vital test of independent nationhood [Emphasis added].

Similarly, Paragraph 12 of the M emorandum asserts that any prospective Trustee for Pal estine would "be faced with a process of virtual partition which has gathered such momentum in recent weeks that not even considerable armed force could now arrest it." In the same vein, paragraph 14 of the M emorandum states: "Palestine is moving forward inexorably towards Partition in a pattern of growing decentralization." Perhaps most revealingly, paragraph 8 contains a direct reference to the military attacks the Y ishuv had been systematically directing at the British mandatory troops, in an effort to drive them out: "[A]ny prolongation of British rule must involve a resumption of the 'squalid war' whosedisastrous effectsforced the Palestine issue upon the attention of the U nited Nations. The war will be all the more squalid because both British and
Jewish opinion have been recently buoyed up by the hope of imminent separation." This last passage appears to amount to no less than athinly veiled threat by the Jewish Agency that the Y ishuv would continue military attacks against any U N-appointed Trustee, in an effort to achievepartition through forceof arms. 39. SC Res. 44 (1 April 1948).

40. See "Trusteeship Agreement," supra note 1.

41. See "Palestine and the Great Powers," supra note 25 , chapter 13.

42. "UN Trusteeship Agreement," supra note 1, articles 20, 21, 22, 23, 24, 25, 26.

43. "UN Trusteeship Agreement," supra note 1, articles 27, 28.

44. "UN Trusteeship Agreement," supra note 1, articles 11, 12, 13, $14,15,16,17,18,19$.

45. SC Res. 43 (1948) of 1 April 1948.

46. SC Res. 46 (1948) of 17 April 1948.

47. SC Res. 48 (1948) of 23 A pril 1948.

48. GA Res. 186 (S-2) (14 May 1948).

49. See SC Res. 49 (1948) of 22 M ay 1948; SC Res. 50 (1948) of 29 May 1948; SC Res. 53 (1948) of 7 July 1948; SC Res. 54 (1948) of 15 July 1948; SC Res. 56 (1948) of 19 August 1948; SC Res. 61 (1948) of 4 November 1948; SC Res. 62 (1948) of 16 November 1948; SC Res. 66 (1948) of 29 December 1948.

50. SeetheUNISPAL website, maintained by the U nited Nations.

51. See "Trusteeship Agreement," supra note 1. The "Preamble" reads as follows:

Preamble

Whereastheterritory known as Pal estine has been administered by the United Kingdom under a $\mathrm{M}$ andate confirmed by the Council of the League of Nations; and

Whereas the United Kingdom was selected as M andatory for Palestine by agreement of the principal allied and associated Powers; and

Whereas Article 75 of the Charter of the $U$ nited N ations provides for the establishment of an International Trusteeship System for the administration and supervision of such territories as may be placed thereunder by subsequent individual agreements; and

Whereas under Article 77 of the said Charter the International Trusteeship System may beapplied to territories now held under mandate; and

Whereas in accordance with Articles 75 and 77 of the said Charter, the placing of a territory under the International Trusteeship System is to be effected by means of a Trusteeship Agreement,

Now therefore, without prejudice to the rights, claims, or position of the parties concerned or to the character of the eventual political settlement, the General Assembly of the United Nations hereby resolves to approve the following terms of trusteeship for Palestine.

Article 5, on "Territorial Integrity," reads as follows:

Article 5. Territorial Integrity

1. Theterritorial integrity of Palestineand itsstatus as defined in this A greement shall be assured by the U nited $\mathrm{N}$ ations. 
2.The Governor-General shall inform the Trusteeship Council of any situation relating to Palestine the continuance of which is likely to endanger the territorial integrity of Palestine, or of any threat of aggression or act of aggression against Palestine, or of any other attempt to alter by force thestatus of Palestineas defined in this A greement. If the Trusteeship Council is not in session and the GovernorGeneral considers that any of the foregoing contingencies is of such urgency as to require immediate action by the United Nations, he shall bring the matter, through the Secretary-General of the United N ations, to the immediate attention of the Security Council.

52. "Trusteeship A greement," supra note 1 . Articles 20 and 21 set out the structure of the Legislature. Note that the "Senate" would have comprised 50 per cent Jews and 50 per cent Arabs, which is the only anti-majoritarian aspect of the political system proposed.

\section{Article 20. Legislature}

1.The Legi slature shall consist of two chambers.

2.The House of Representatives shall be composed of Palestinian citizens twenty-five years of age or older elected from single-member districts, each of which districts shall be a geographical unit with a population approximately equal in number to that of every other electoral district.

3.The Senate shall be composed of thirty Palestinian citizens twenty-five years of age or older elected in equal numbers by the registered members of the Arab and Jewish communities in Palestine. The Arab representation shall consist of Moslems, Christians, and Druses in proportion to their numbers in the Arab population.

4.Legislative provision may be made as to disqualification for election to or membership in either chamber of the Legislature resulting from loss of legal capacity.

5.Remuneration of members of both chambers of the Legislature shall be determined by legislation.

Article 21. Elections to the Legislature

1.The members of both chambers of the Legislature shall be elected by the citizens of Palestine, twenty-one years of age and over, on the basis of universal suffrage and by secret ballot.

2.Legislative provision may be made as to disqualification from voting resulting from loss of legal capacity.

53. "Trusteeship Agreement," supra note 1. The full text of Article 9, on "Fundamental Human Rights and Freedoms," reads as follows:

Article 9. Fundamental Human Rights and Freedoms

1.All persons in Palestine shall enjoy freedom of conscience and shall, subject only to the requirements of public order, public morals and public health, enjoy all other fundamental human rights and freedoms, including freedom of religion and worship, language, education, speech and Press, assembly and association, and petition, including petition to the Trusteeship Council.
2.No discrimination of any kind on grounds of race, religion, language or sex shall be made against any person in Palestine.

3.All persons in Palestine shall be entitled to equal protection of the laws.

4.No person within Palestine may be arrested, detained, convicted, or punished except according to legal process. 5.N o person or property within Palestine shall be subject to search or seizure except according to legal process. 6.The legislation of Palestine shall ensure that accused persons shall have adequate rights of defence.

7.The legislation of Palestine shall neither place nor recognize any restriction upon the free use by any person of any language in private intercourse, in religious matters, in commerce, in the Press or in publications of any kind, or at public meetings.

8.Except as may be required for the maintenance of public order, good government and public health, no measure shall be taken to obstruct or interfere with the enterprise of religious or charitable bodies of all fai ths. No measure shall be taken which discriminates on grounds of religion or nationality against any representative or member of such bodies.

9.The family law and person status of the various persons and communities and their religious interests, including endowments, shall be respected.

Article32, on "Education System and Cultural and Benevolent Institutions," contains Paragraph 1, that reads as follows:

Article 32. Educational System and Cultural and Benevolent Institutions

1.Education in Palestine shall be directed to the full physical, intellectual, moral and spiritual development of the human personality, to thestrengthening of respect for human rights and fundamental freedoms and to the combating of the spirit of intoleranceand hatred against other nationsor racial or religious groups [emphasis added].

54. "Trusteeship A greement," supra note 1. Article29, on "I mmigration," reads as follows:

Article 29. Immigration

1.Immigration into Palestine shall be permitted, without distinction between individuals as to religion or blood, in accordance with the absorptive capacity of Palestine as determined by the Governor-General, and shall be subject to the requirements of public order and security and of public morals and public health.

2.Asatemporary measure, theimmigration of [N.B.: blank space appears in original draft text] Jewish displaced persons per month, for a period of two years, shall be permitted into Palestine. The selection and administration of the immigration of Jewish displaced persons into Palestine shall be conducted by the Governor-General in consultation with the International Refugee Organization and representatives of the communities in Palestine. 
55. For analysis of the international law bases of the individually held right of return of the 1948 Palestinian refugees-including refutation of the Israeli claim that return is barred on grounds of "citizenship" - see, e.g., J. Quigley, "Displaced Palestinians and a Right of Return" (Winter 1998) 39:1 H arvard International Law Journal 171; J. Quigley, "M ass Displacement and the Individual Right of Return," in British Yearbook of International Law, Vol. 68 (1997) 65; G. J. Boling, The 1948 Palestinian Refugees and the Individual Right of Return: An International Law Analysis (Bethlehem: BADIL, 2001). For further analysis of the right of return under international law generally, see W.T. Mallison and S. Mallison, "The Right to Return" (1980) 9 Journal of Palestine Studies 125; W.T. M allison and S. Mallison, An International Law Analysis of the Major U nited Nations Resolutions Concerning the Palestine Question, UN Doc. ST/SG/SER.F/4, U.N. Sales \#E.79.I.19 (1979); W .T. M allison and S. M allison, The Palestine Problem in International Law and W orld O rder (Essex: Longman, 1986) 174-188; K. Lawand, "The Right to Return of Palestinians in International Law" (1996) 8:4 International Journal of Refugee Law 532.

56. "Trusteeship Agreement," supra note 1, art. 8.

57. For useful discussions of Israel's land confiscation laws, used to confiscatethe entireland and property holdings of the 1948 Palestinian refugees, which were subsequently transferred to exclusive use by Jewish citizens of Israel, see S. Jiryis, "Settlers' Law: Seizure of Palestinian Lands" 2 Palestine Yearbook of International Law 17 (1985); S. Jiryis, "The Legal Structure for the Expropriation and Absorption of Arab Lands in Israel" (1973) 8 Journal of Palestine Studies 82; D. Peretz, Israel and the Palestine Arabs (Washington, D.C.: M iddle East Institute, 1958); D . Peretz, Palestinian RefugeeC Compensation (Washington, D.C.: Center for Policy Analysis on Palestine, 1995); J. Quigley, Palestine and Israel: A Challenge to Justice (Durham and London: Duke University Press, 1990); G. J. Boling, “ 'Absentees' Property' Laws and Israel's Confiscation of Palestinian Property: A Violation of U.N. General Assembly Resolution 194 and International Law," 11 Palestine Yearbook of International Law 73 (2000-2001).

58. "Trusteeship Agreement," supra note1, art. 9(2), art. 9(3), and art. 9(5).

59. "Trusteeship Agreement," supra note 1, art. 31.

60. See, e.g., "Trusteeship Agreement," supra note 1. The preamble specifically cites Article 77 of the Charter of the United Nations: "Whereas under Article 77 of the said Charter [of the UN] the International Trusteeship System may be applied to territories now held under mandate..."

61. "Charter of the U nited N ations," supra note 4, art. 73.

62. Id., art. 76(b), art. 76(c).

63. For analysis and comparative studies on the UN Trusteeship system, generally, see R.N . Chowdhuri, International $M$ andates and Trusteeship Systems: A Comparative Study (The Hague: M artinus Nijhoff, 1955) ; J. N. M urray, J r., The U nited Nations Trusteeship System (U rbana: University of Illinois Press, 1957); G. Thullen, Problems of theT rusteeship System: A
Study of Political Behavior in the U nited Nations (Geneva: Librairie Droz, 1964); E. J. Sady, The United Nations and Dependent Peoples (W ashington, D.C.: TheBrookings Institution, 1956); C. V. Lakshmi-Narayan, Analysis of the Principles and System of International Trusteeship in the Charter: A Study of the Origin, Principles and Application in International Law (Geneva: Imprimeries Popularies, 1951).

64. "Charter of the United Nations," supra note 4, art. 1(2) ("To develop friendly relationsamong nations based on respect for the principle of equal rights ... of peoples..." [emphasis added]).

65. Id., art. 1(3) ("... and in promoting and encouraging respect for human rightsand for fundamental freedoms for all without distinction as to race, sex, language or religion..." [emphasis added]).

66. Id., art. 1(2) ("To develop friendly relations among nations based on respect for the principle of ... self-determination of peoples..." [emphasis added]).

67. Id., art. 55 ("With a view to the creation of conditions of stability and well-being which are necessary for peaceful and friendly relations among nations based on respect for the principle of equal rights and self-determination of peoples, the U nited N ations shall promote: ... (c) universal respectfor, and observance of, human rights and fundamental freedoms for all without distinction as to race, sex, language or religion." [emphasis added])

68. Id., art. 56 (all member states of the UN "pledge themselves to take joint and separate action in cooperation with the [UN ] Organization for the achievement of the purposes set forth in Article 55.")

69. Id., art. 1(1) ("To maintain international peace and security, and to that end: to take effective collective measures for the prevention and removal of threats to the peace, and for the suppression of acts of aggression or other breaches of the peace, and to bring about by peaceful means, and in conformity with the principles of justice and international law, adjustments or settlement of international disputes or situations which might lead to a breach of the peace." [emphasis added]).

70. Id., art. 2(3) ("All M embers shall settle their international disputes by peaceful means in such a manner that international peace and security, and justice, are not endangered."); art. 2(4) ("All members shall refrain in their international relations from the threat or use of force against the territorial integrity or political independence of any state, or in any other manner inconsistent with the Purposes of the United Nations.")

71. "Trusteeship Agreement," supra note 1, art. 47. Article 47 reads as follows:

\section{Article 47. Termination of Trusteeship}

1. In order to enable the inhabitants of Palestine to attain full self-government as soon as possible, it shall be the responsibility of the Governor-General to take all possible steps to bring about agreement between the Palestinian Jewish and Arab communities, acting through their repre sentatives in the Legislature, upon a plan of government for Palestine. 
2. This Agreement shall terminate (a) as soon as the $\mathrm{Ge}$ neral Assembly has approved a plan of government agreed upon in accordance with paragraph 1 above and such plan of government is established, or (b) whenever, after the expiration of three years from the effective date of this Agreement, the General Assembly, upon recommendation of the Trusteeship Council, shall agree upon a plan of government for Palestine, which is approved by a minority [sic] of both the Arab and J ewish communities of Pal estine by means of a plebiscite conducted by the GovernorGeneral.

72. "Charter of the United Nations," supra note 4, art. 80(1) ([N ] othing in this Chapter [Chapter XII, titled "International Trusteeship System] shall be construed in or of itself to alter in any manner therights whatsoever of any statesor any peoples or theterms of existinginternational instruments to which $\mathrm{M} \mathrm{em}$ bers of the U nited Nations may respectively be parties" [emphasis added]).

73. "Universal Declaration of H uman Rights," GA Res. 217A (III), UN Doc. A/810, at 71 (1948), adopted 10 December 1948 [hereinafter "U niversal Declaration of H uman Rights"].

74. For a detailed account of the drafting history ("Travaux Pré paratoires") of the UDHR, see J. M orsink, The U niversal DecIaration of Human Rights: Origins, Drafting, and Intent (Philadelphia: University of Pennsylvania, 1999). For other historical studies of the UDHR, including detailed commentaries on it, see, e.g., G. Alfredsson and A. Eide, eds., The U niversal Declaration of $H$ uman Rights: A Common Standard of Achievement (Martinus Nijhoff, 1999); F. M. baron van Asbeck, The U niversal Dedaration of Human Rights and Its Predecessors (1679-1948) (Leiden: E. J. Brill, 1949); A. Eide, et al., TheU niversal Declaration of H uman Rights: A Commentary (Scandinavian University Press and Oxford, 1992).

75. "Universal Declaration of H uman Rights," supra note 63, art. 13, art. 9, art. 15, art. 17, art. 21, art. 29, art. 30, art. 7, art. 2.

Gail J. Boling is a Senior Researcher at Birzeit University's Institute of Law (W est Bank, Palestine). She received her B.A. from the U niversity of Chicago (1982); J.D. from O hio State U niversity College of Law (1994); and was admitted to practice in Illinois. 